\title{
PENGARUH IKLIM ORGANISASI, MOTIVASI DAN KEDISIPLINAN YANG DIPERKUAT OLEH SKILLS TERHADAP KINERJA KARYAWAN LPPKS INDONESIA
}

\author{
Farika Chandrasari \\ Universitas Islam Indonesia \\ farika1607@yahoo.com
}

\begin{abstract}
Tujuan dari penelitian ini adalah untuk mengetahui pengaruh pengaruh iklim organisasi, motivasi dan kedisiplinan yang diperkuat oleh skills terhadap kinerja karyawan LPPKS Indonesia. Data penelitian adalah 40 orang dengan jumlah sampel 36 orang, dan objek penelitian penulis adalah iklim organisasi dan motivasi, kedisiplinan, skills, dan kinerja karyawan. Metode yang digunakan dalam penarikan sampel ini adalah simple random sampling (Sugiyono, 2002). Dari hasil penelitian yang dilakukan didapatkan bahwa semakin baik iklim organisasi dan motivasi maka kedisiplinan dan kinerja karyawan akan semakin tinggi, semakin baik iklim organisasi dan kedisiplinan maka kinerja karyawan akan semakin tinggi. Berbeda dengan motivasi yang mempunyai pengaruh kecil dalam meningkatkan kinerja, motivasipun tidak terlalu berpengaruh secara simultan dengan iklim organisasi terhadap kinerja karyawan dimana iklim organisasi, motivasi, dan kedisiplinan secara simultan berpengaruh terhadap kinerja karyawan, dan motivasi juga tidak terlalu berpengaruh secara simultan dengan iklim organisasi terhadap kinerja karyawan. Adanya variabel skills yang semakin baik maka kinerja karyawan akan semakin tinggi.
\end{abstract}

Kata kunci : Iklim Organisasi, Motivasi, Kedisiplinan, Skills, Kinerja Karyawan

(C) 2017 JBTI. All rights reserved

Article history : received 02 Ags 2017; revised 12 Ags 2017; accepted 05 Sep 2017

\section{PENDAHULUAN}

Pendidikan merupakan tonggak utama dalam membangun generasi muda yang berkualitas dan memiliki kompetensi diri dalam menghadapi era globalisasi yang ada dan pendidikan dilakukan di sekolah yang terdapat banyak pengajar/guru dengan berbagai macam kompetensi ilmu yang selalu memberikan sistem pengajaran yang bertujuan baik kepada siswanya dan komunitas sekolah memiliki satu kepala sekolah sebagai leading sector yang bertugas untuk memanajemen sistem pendidikan dengan tidak melupakan tugas utamanya sebagai pendidik karena pada hakekatnya kepala sekolah adalah guru yang memiliki tugas tambahan sebagai kepala sekolah sesuai dengan Permendiknas Nomor 28 Tahun 2010. Lembaga Pengembangan dan Pemberdayaan Kepala Sekolah (LPPKS) Indonesia didirikan dengan SK Menteri Pendidikan pada tanggal 9 Februari 2009 merupakan lembaga yang melaksanakan Permendiknas Nomor 28 Tahun 2010 yang telah direvisi dengan Permendikbud No. 39 Tahun 2012 dengan tugas dan fungsi melaksanakan penyiapan, pengembangan, dan pemberdayaan Kepala Sekolah dari semua jenjang pendidikan. Iklim organisasi pada LPPKS belum terlihat kondusif, karena adanya keberagaman eselon dan jabatan kadang menyulut perbedaan antar pimpinan yang mengakibatkan kinerja karyawan terganggu. Ditambah 
dengan tupoksi LPPKS yang banyak, membuat unsur pimpinan dan karyawan harus saling bekerjasama dalam melaksanakan tugas dan pekerjannya.

LPPKS memiliki karyawan dengan latar belakang dan motivasi kerja yang berbeda sehingga upaya untuk menyamakan persepsi terus dilakukan agar setiap karyawan memiliki rasa memiliki dan akan berkerja maksimal. Unsur pimpinan selalu berusaha menumbuhkan motivasi kerja karyawan dari dalam diri pribadi sehingga output yang diinginkan adalah para karyawan memiliki motivasi yang tumbuh dari dalam dirinya sendiri yang akan menjadikan para karyawan bekerja secara ikhlas dan bersungguh sungguh. Dengan beban kerja yang berat dan beragam dalam melaksanakan tupoksinya, setiap karyawan belum memiliki dedikasi yang kuat dan disiplin yang tinggi dalam melaksanakan setiap tahapan sehingga semua selesai tepat pada waktunya dengan hasil optimal. Karyawan LPPKS memiliki skills yang berbeda tergantung dari latar belakang pendidikannya dan semua kemampuan tersebut ada yang belum mendukung dalam melaksanakan semua tugas pokok dan fungsi lembaga. Keberagaman skills tersebut seharusnya menjadi sarana untuk dapat saling membantu antara karyawan sehingga semua bidang dapat dilaksanakan sesuai dengan peran dan tugasnya masing-masing.

\section{KAJIAN TEORI}

\section{A. Iklim Organisasi}

Definisi pertama dikemukakan oleh Forehand and Gilmers pada tahun 1964, yang menyatakan bahwa iklim organisasi adalah serangkaian deskripsi dari karakteristik organisasi yang bertahan dalam jangka waktu lama (Toulson dan Smith, 1994). Pada tulisan Litwin dan Stringer, seperti dikutip Toulson dan Smith (1994) mendefinisikan iklim organisasi sebagai suatu yang dapat diukur pada lingkungan kerja baik secara langsung maupun tidak langsung berpengaruh pada karyawan dan pekerjaannya dimana tempat mereka bekerja dengan asumsi akan berpengaruh pada motivasi dan perilaku karyawan. Iklim organisasi menurut Purnomosidhi (1996) adalah suatu kondisi atau suasana organisasi yang diciptakan oleh berbagai komponen yang membentuk suatu nilai kebijaksanaan dimana pelaksanaannya sesuai dengan kepentingan bersama. Menurut Newstrom dan Davis (1996), iklim organisasi adalah lingkungan manusia yang di dalamnya pada karyawan suatu organisasi melakukan pekerjaan mereka. Simamora (2001) menyebutkan bahwa iklim organisasi adalah lingkungan internal atau psikologi organisasi. Davis dan Newstrom (2001) memandang iklim organisasi sebagai kepribadian sebuah organisasi yang membedakan dengan organisasi lainnya yang mengarah pada persepsi masing-masing anggota dalam memandang organisasi. Stringer (2002) mendefinisikan iklim organisasi sebagai kualitas lingkungan internal organisasi yang secara relatif terus berlangsung, dialami oleh anggota organisasi, mempengaruhi perilaku mereka dan dapat dilukiskan dalam pengertian satu set karakteristik atau sifat organisasi.

Toulson dan Smith (1994) menerangkan dalam jurnalnya bahwa konsep iklim organisasi pertama kali dikemukakan oleh Litwin dan Stringer pada tahun 1968. Iklim organisasi oleh Litwin dan Stringer, dijabarkan atau diukur melalui lima dimensi, yaitu: (a.) Responsibility (tanggung jawab), adalah perasaan menjadi pimpinan bagi diri sendiri, tidak selalu harus mengecek ulang semua keputusan yang diambil, ketika karyawan mendapat suatu pekerjaan, karyawan yang bersangkutan mengetahui bahwa itu adalah pekerjaannya; (b.) Identity (identitas), adalah perasaaan memiliki (sense of belonging) terhadap perusahaan dan diterima dalam kelompok; (c.) Warmth (kehangatan), adalah perasaan terhadap suasana kerja yang bersahabat dan lebih ditekankan pada kondisi keramahan atau persahabatan dalam kelompok yang informal, serta hubungan yang baik antar rekan kerja, penekanan pada pengaruh persahabatan dan kelompok sosial yang informal; (d.) Support (dukungan), adalah hal-hal yang terkait dengan dukungan dan hubungan antar sesama rekan kerja yaitu perasaan saling menolong antara manajer dan karyawan, lebih ditekankan pada 
dukungan yang saling membutuhkan antara atasan dan bawahan; dan (e.) Conflict (konflik), merupakan situasi terjadi pertentangan atau perbedaan pendapat antara bawahan dengan pimpinan dan bawahan dengan bawahan. Ditekankan pada kondisi dimana manajer dan para pekerja mau mendengarkan pendapat yang berbeda. Kedua belah pihak bersedia menempatan masalah secara terbuka dan mencari solusinya daripada menghindarinya. Jadi dapat disimpulkan bahwa iklim organisasi adalah serangkaian deskripsi dari karakteristik organisasi yang membedakan sebuah organisasi dengan organisasi lainnya yang mengarah pada persepsi masing-masing anggota dalam memandang organisasi.

\section{B. Motivasi}

Motivasi berasal dari kata latin movere yang berarti dorongan atau menggerakkan. Secara konkrit motivasi dapat diberi batasan sebagai "Proses pemberian motif (penggerak) bekerja kepada para bawahan sedemikian rupa sehingga mereka mau bekerja dengan ikhlas demi tercapainya tujuan organisasi secara efisien", Sarwoto (1979). Menurut Siagian (1995) "Motivasi adalah daya dorong yang mengakibatkan seseorang anggota organisasi mau dan rela untuk mengerahkan kemampuan dalam bentuk keahlian atau ketrampilan, tenaga dan waktu untuk menyelenggarakan berbagai kegiatan yang menjadi tanggungjawabnya dan menunaikan kewajibannya dalam rangka pencapaian tujuan dan berbagai sasaran organisasi yang telah ditentukan sebelumnya“. Motivasi penting karena dengan motivasi ini diharapkan setiap individu karyawan mau bekerja keras dan antusias untuk mencapai produktivitas kerja yang tinggi. Hasibuan (1996), mengatakan bahwa motivasi adalah pemberian daya penggerak yang menciptakan kegairahan kerja seseorang, agar mereka mau bekerjasama, bekerja efektif dan terintegrasi dengan segala daya upayanya untuk mencapai kepuasan. Robbins (2000) menyatakan bahwa "Motivasi adalah kesediaan untuk mengeluarkan tingkat upaya yang tinggi ke arah tujuan organisasi yang dikondisikan oleh kemampuan upaya itu untuk memenuhi sesuatu kebutuhan individual “. Hasibuan (2005) menyatakan bahwa "Motivasi adalah pemberian daya penggerak yang menciptakan kegairahan kerja seseorang agar mereka mau bekerja sama, bekerja efektif dan terintegrasi dengan segala daya upayanya untuk mencapai kepuasan". Menurut Mangkunegara (2007), "Motivasi adalah kondisi yang menggerakan pegawai agar mampu mencapai tujuan dari motifnya".

Teori motivasi merupakan teori-teori yang membicarakan bagaimana motivasi manusia di dalam melaksanakan pekerjaan dan mencapi tujuan, yang dipengaruhi oleh berbagai faktor pembentuk terciptanya motivasi. Untuk memahami motivasi karyawan dalam penelitian ini digunakan teori motivasi dua arah yang dikemukakan Herzberg karena teori yang dikembangkan Herzberg berlaku mikro yaitu untuk pegawai pemerintahan yang hubungannya antara kebutuhan dengan performa pekerjaan. Faktor-faktor motivasi menurut Herzberg dalam Hasibuan (2005) yang disebut faktor intrinsik untuk mengukur kepuasan kerja meliputi: (a.) Tanggung jawab (Responsibility); (b.) Prestasi yang diraih (Achievement); (c.) Pengakuan orang lain (Recognition); (d.) Pekerjaan itu sendiri (The work it self); (e.) Kemungkinan Pengembangan (The possibility of growth); dan (f.) Kemajuan (Advancement). Sedangkan menurut Herzberg dalam Luthans (2003), faktor ekstrinsik untuk mengukur ketidakpuasan kerja antara lain : (a.) Gaji; (b.)Keamanan dan keselamatan kerja; (c.) Kondisi kerja; (d.) Hubungan kerja; (e.) Prosedur perusahaan; dan (f.) Status.

\section{Kedisiplinan}

Disiplin berasal dari kata latin, yaitu disciplina yang artinya latihan atau pendidikan, kesopanan dan kerohanian serta pengembangan tabiat. Menurut Hadari Nawawi (2000) bahwa "Disiplin merupakan usaha untuk menanamkan kesadaran pada setiap personil tentang tugas dan tanggung jawab atas semua pekerjaan”. Menurut Davis dalam Mangkunegara (2000) menyatakan 
bahwa kedisiplinan dapat diartikan sebagai pelaksanaan manajemen untuk memperteguh pedomanpedoman organisasi dan disiplin adalah suatu proses yang dapat menumbuhkan perasaan seseorang untuk mempertahankan dan meningkatkan tujuan organisasi secara obyektif, melalui kepatuhannya menjalankan peraturan organisasi. Soejono Soekanto (2001) menyatakan bahwa "Disiplin adalah keadaan dimana perilaku seseorang mengikuti pola-pola tertentu yang telah ditetapkan terlebih dahulu". Heidjrachman dan Husnan (2002) mengungkapkan bahwa "Disiplin adalah setiap perseorangan dan juga kelompok yang menjamin adanya kepatuhan terhadap perintah dan berinisiatif untuk melakukan suatu tindakan yang diperlukan seandainya tidak ada perintah". Menurut Siagian (2003) menyatakan bahwa "Disiplin merupakan sikap dan tingkah laku seseorang yang mencerminkan tingkat kepatuhan atau ketaatannya pada berbagai ketentuan yang berlaku dan tindakan korektif terhadap pelanggaran atas ketentuan atau standar yang telah ditetapkan". Hasibuan (2005) mendefinisikan bahwa kedisiplinan adalah kesadaran dan kesediaan seseorang menaati semua peraturan perusahaan dan norma-norma yang berlaku. Dalam Peraturan Pemerintah Nomor 53 tahun 2010 tentang Peraturan Disiplin Pegawai Negeri Sipil juga telah diatur secara jelas kewajiban dan larangan yang harus ditaati oleh setiap pegawai negeri sipil di seluruh wilayah Republik Indonesia.

Menurut Byars and Rue (1995) menyatakan ada beberapa hal yang dapat dipakai sebagai indikasi tinggi rendahnya kedisiplinan kerja karyawan, yaitu: (1) ketepatan waktu, (2) kepatuhan terhadap atasan, (3) peraturan terhadap perilaku terlarang, dan (4) ketertiban terhadap peraturan yang berhubungan langsung dengan produktivitas kerja. Menurut Davis (2000) ada beberapa indikator kedisiplinan antara lain adalah: (a.) Kehadiran; (b.) Tata cara kerja; (c.) Ketaatan pada atasan; (d.) Kesadaran bekerja; dan (e.) Tanggung jawab.

Hasibuan (2005) menyatakan bahwa pada dasarnya banyak indikator yang mempengaruhi tingkat kedisiplinan karyawan suatu organisasi, di antaranya adalah: (a.) Tujuan dan kemampuan; (b.) Teladan pimpinan; (c.) Balas Jasa; (d.) Keadilan; (e.) Waskat (pengawasan melekat); (f.) Sanksi hukuman; (g) Ketegasan; dan (h.) Hubungan kemanusiaan.

\section{Skills}

Hard skills didefinisikan sebagai kemampuan menguasai ilmu pengetahuan (knowledge), teknologi dan kemampuan teknis yang berhubungan dengan bidang ilmunya dan lebih mudah diseleksi karena dapat langsung dilihat pada ijazah pendidikan melalui indeks prestasi, pengalaman kerja, dan ketrampilan yang dikuasai. Sedangkan soft skills adalah kemampuan yang digunakan dalam berinteraksi, berhubungan, dan bekerja sama dengan orang lain, yang biasanya dievaluasi oleh psikolog melalui psikotes dan wawancara mendalam, meskipun tidak dijamin 100\% benar namun sangat membantu dalam menempatkan karyawan sesuai dengan the right person in the right place'. Ichsan S. Putra (2005) menurut survei yang diterbitkan National Association of Colleges and Employers (NACE) pada tahun 2002 di Amerika Serikat, dari hasil 457 pengusaha, diperoleh kesimpulan bahwa IP hanyalah nomor 17 dari 20 kualitas yang dianggap penting dari seseorang lulusan universitas. Kualitas yang duduk di peringkat atas justru hal-hal yang dianggap sekedar basa basi ketika tertulis di iklan lowongan kerja. Misalnya kemampuan berkomunikasi, integritas dan kemampuan bekerja sama dengan orang lain. Kualitas-kualitas yang tidak terlihat wujudnya (intagible) namun sangat diperlukan ini disebut juga soft skills. Secara umum dapat dikatakan bahwa kemampuan soft skills memegang peranan sangat besar dibandingkan dengan hard skills.

Hard skills merupakan faktor penting dalam bekerja, namun keberhasilan seseorang dalam bekerja biasanya lebih ditentukan oleh soft skillsnya yang baik. Psikolog kawakan, David McClelland bahkan berani berkata bahwa faktor utama keberhasilan para eksekutif muda dunia adalah kepercayaan diri, daya adaptasi, kepemimpinan dan kemampuan mempengaruhi orang lain. Yang tak lain dan tak bukan merupakan soft skills. Soft skills adalah: (1) Karakter yang melekat pada diri 
seseorang dan sudah dibangun sejak kecil (didikan lingkungan dan keluarga); (2) Kemampuan yang tidak terlihat; dan (3) Kemampuan interpersonal diri pribadi seseorang diluar kemampuan akademiknya (kecerdasan emosi, semangat, ambisi, empati, dll). Interpersonal skills ini meliputi : manajemen waktu, punya goalsetting dan tujuan hidup yang jelas, kemampuan komunikasi, kemampuan sosialisasi (berhubungan dengan orang lain), kepemimpinan, kemampuan berbicara di depan publik/khalayak ramai. Soft skills menurut Berthal dan Illah Sailah (2008) dapat diartikan sebagai "Personal and interpersonal behaviors that develop and maximize human performance (eg. coaching, team building, decision making, and initiative). Soft skills dont include technical skills such as financial, computer or assembly skills". Sedangkan menurut Owen dan Schatzberg dalam Tarmidi (2010), soft skills adalah mereka yang terbuka menerima bimbingan, mampu bekerja dalam lingkungan yang beragam dan mampu meresolusikan konflik. "Soft skills adalah kemampuan-kemampuan tak terlihat yang diperlukan untuk sukses, misalnya kemampuan bekerja sama, integritas, dan lain-lain," Pratiwi dan Putra (2005).

Menurut Ramdhani (2008) dalam Hafis Mu'addab (hafismuaddab.wordpress.com), soft skills sering juga disebut keterampilan lunak adalah keterampilan yang digunakan dalam berhubungan dan bekerjasama dengan orang lain. Secara garis besar keterampilan ini dapat dikelompokkan ke dalam: (1) Process Skills; (2) Social Skills; dan (3) Generic Skills. Aribowo dalam Hafis Mu'addab, membagi soft skills atau people skills menjadi dua bagian, yaitu intrapersonal skills dan interpersonal skills. Intrapersonal skills adalah keterampilan seseorang dalam "mengatur" diri sendiri. Intrapersonal skills sebaiknya dibenahi terlebih dahulu sebelum seseorang mulai berhubungan dengan orang lain. Adapun Interpersonal skills adalah keterampilan seseorang yang diperlukan dalam berhubungan dengan orang lain. Dua jenis keterampilan tersebut dirinci sebagai berikut: Intrapersonal Skill adalah : (1) Transforming Character, (2) Transforming Beliefs,(3) Change management, (4) Stress management, (5) Time management, (6) Creative thinking processes, (7) Goal setting \& life purpose, dan (8) Accelerated learning techniques. Interpersonal Skill adalah : (1) Communication skills, (2) Relationship building, (3) Motivation skills, (4) Leadership skills, (5) Self-marketing skills, (6) Negotiation skills, (7) Presentation skills, dan (8) Public speaking skills.

Dalam penelitian ini, skills dijadikan sebagai variabel moderating karena sifatnya yang membentuk karakter karyawan yang akan menunjang produktivitas dan menjadikan kinerja karyawan meningkat sehingga visi dan misi organisasi dapat tercapai.

\section{E. Kinerja}

Kinerja merupakan terjemahan dari bahasa Inggris dari kata work performance atau job performance atau biasa disingkat dengan performance saja. Dalam bahasa Indonesia disebut juga dengan prestasi kerja yang diartikan sebagai kesuksesan seseorang dalam melakukan pekerjaan. Berdasarkan pengertian tersebut job performance dapat diartikan sebagai hasil yang dicapai seseorang menurut ukuran yang berlaku untuk pekerjaan yang bersangkutan. Menurut Prawirosentono (1997) kinerja adalah hasil kerja yang dapat dicapai oleh seseorang atau sekelompok orang dalam suatu organisasi sesuai dengan wewenang dan tanggung jawabnya masing-masing dalam upaya mencapai tujuan organisasi bersangkutan secara legal, tidak melanggar hukum dan sesuai dengan moral maupun etika. Kinerja adalah hasil kerja secara kualitas dan kuantitas yang dicapai oleh seorang pegawai dalam melaksanakan tugasnya sesuai dengan tanggung jawab yang diberikan kepadanya, Mangkunegara (2001). Menurut Guilbert dalam Hasibuan (2001) kinerja adalah sesuatu yang dapat dikerjakan seseorang sesuai dengan bidang tugas dan fungsinya yang dipengaruhi oleh sikap, pengetahuan dan ketrampilan. Lawler dan Poter dalam As'ad (2003) menyatakan bahwa kinerja adalah succesfull role achievement yang diperoleh seseorang dari perbuatan-perbuatannya. Jadi kinerja atau prestasi kerja (performance) diartikan sebagai ungkapan kemampuan yang didasari oleh pengetahuan, sikap, ketrampilan, motivasi dan kedisiplinan dalam menghasilkan sesuatu. Menurut Mahsun (2006) bahwa kinerja adalah gambaran mengenai tingkat 
pencapaian pelaksanaan suatu kegiatan/program, kebijakan dalam mewujudkan sasaran, tujuan, visi dan misi organisasi yang tertuang dalam strategic planning suatu organisasi. Sedarmayanti (2007) menyatakan bahwa kinerja merupakan sistem yang digunakan untuk menilai dan mengetahui apakah seorang karyawan telah melaksanakan pekerjaannya secara keseluruhan, atau merupakan perpaduan dari hasil kerja (apa yang harus dicapai seseorang) dan kompetensi (bagaimana seseorang mencapainya). Lebih lanjut Wibowo (2007) menyatakan bahwa kinerja adalah tentang melakukan pekerjaan dan hasil yang dicapai dari pekerjaan tersebut. Kinerja adalah tentang apa yang dikerjakan dan bagaimana cara mengerjakannya. Kinerja adalah kesediaan seseorang atau kelompok orang untuk melakukan sesuatu kegiatan dan menyempurnakannya sesuai dengan tanggung jawabnya dengan hasil seperti yang diharapkan. Sedangkan Rivai (2008) mengatakan bahwa kinerja merupakan perilaku nyata yang ditampilkan setiap orang sebagai prestasi kerja yang dihasilkan oleh karyawan sesuai dengan perannya dalam perusahaan.

Kinerja merupakan gambaran tingkat pencapaian pelaksanaan suatu kegiatan/program dalam mewujudkan sasaran, tujuan, misi dan visi organisasi. Menurut Prawirosentono (1999) menyatakan faktor-faktor yang mempengaruhi kinerja antara lain : efektivitas dan efisiensi, wewenang, disiplin, inisiatif, motivasi, semangat kerja. Suprihanto (2000) faktor-faktor yang mempengaruhi kinerja pegawai antara lain : bakat, pendidikan dan latihan, lingkungan dan fasilitas, iklim kerja, motivasi dan kemampuan hubungan industrial, teknologi manajemen, kesempatan berprestasi dan lain sebagainya. Faktor-faktor lain yang mempengaruhi pencapaian kinerja adalah faktor kemampuan (Ability) dan faktor motivasi (Motivation). Hal ini sesuai dengan pendapat Keith Davis (1994) yang dikutip oleh Mangkunegara (2001) mengemukakan bahwa faktor-faktor yang mempengaruhi kinerja adalah faktor Motivasi dan faktor Kemampuan. Menurut Malayu S.P Hasibuan dalam buku Manajemen Sumber Daya Manusia (2007) bahwa unsur-unsur yang dinilai dalam kinerja adalah: (a.) Kesetiaan; (b.) Hasil kerja; (c.) Kejujuran; (d.) Kedisiplinan; (e.) Kreativitas; (f.) Kerja sama; (g.) Kepemimpinan; (h.) Kepribadian; (i.) Prakarsa; (j.) Kecakapan; dan (k.) Tanggung jawab. Menurut Hendri Simamora (2001), penilaian kinerja adalah suatu proses dimana organisasi mengevaluasi pelaksanaan kerja individu. Terdapat beberapa indikator kinerja karyawan yaitu: (a.) Loyalitas; (b.) Semangat kerja; (c.) Kepemimpinan; (d.) Kerjasama; (f.) Tanggung jawab; dan (g.) Pencapaian target.

Teknik paling tua yang digunakan oleh pimpinan organisasi untuk meningkatkan kinerja adalah melalui penilaian (appraisal) motivasi pegawai untuk bekerja, mengembangkan kemampuan pribadi, dan meningkatkan kemampuan di masa mendatang dipengaruhi oleh umpan balik mengenai kinerja masa lalu dan pengembangan (Simamora, 2001). Kreitner (2003) menyatakan penilaian kinerja melibatkan evaluasi terhadap penilaian atas ciri-ciri, perilaku atau prestasi seorang pemegang jabatan sebagai pembuat keputusan personalia yang penting dan program yang penting . Dessler (2000) menyatakan bahwa yang dapat melakukan penilaian kinerja adalah: (1) Atasan langsung; (2) Rekan sekerja; (3) Panitia atau komite; dan (4) Bawahan.

\section{METODE PENELITIAN}

\section{A. Subjek dan Objek Penelitian}

Dalam penelitian ini yang menjadi subjek penelitian ini adalah karyawan pada LPPKS Indonesia yang berfungsi sebagai tenaga fungsional yang berjumlah 40 orang dengan jumlah sampel 36 orang, dan objek penelitian penulis adalah iklim organisasi dan motivasi, kedisiplinan, skills, dan kinerja karyawan. Metode yang digunakan dalam penarikan sampel ini adalah simple random sampling (Sugiyono, 2002). Dalam pengambilan sampel dalam penelitian ini menggunakan metode Isaac dan Michael, yang mengembangkan penentuan jumlah sampel untuk tingkat kesalahan $1 \%, 5 \%$, dan $10 \%$. 


\section{B. Variabel dan Definisi Operasional}

Variabel penelitian adalah sebagai berikut : (1.) Variabel eksogen yaitu iklim organisasi (X1) dan motivasi (X2). Kedisiplinan (Y1) yang menjadi variabel endogen bagi X1 dan X2 juga akan menjadi variabel eksogen ketika berfungsi sebagai variabel yang menjelaskan variabel kinerja (Y2); (2.) Variabel Intervening (eksogen/endogen) adalah kedisiplinan (Y1); (3.) Variabel Moderating adalah skills (Z); dan (4.) Variabel Endogen adalah kinerja pegawai (Y2). Pemberian skor dilakukan atas jawaban pertanyaan baik mengenai iklim organisasi (X1), motivasi (X2), kedisiplinan (variabel Y1), skills (variabel Z), dan kinerja karyawan (variabel Y2), karena data ini berskala ordinal. Selanjutnya nilai-nilai dari alternatif tersebut dijumlahkan untuk setiap responden. Definisi operasional merupakan petunjuk tentang bagaimana suatu variabel di ukur, sehingga peneliti dapat mengetahui baik buruknya pengukuran tersebut.

\section{Jenis dan Metode Pengumpulan Data}

Penelitian ini menggunakan data kuantitatif dan diperoleh melalui teknik penyebaran instrumen kuesioner kepada responden. Penyebaran instrumen menggunakan skala likert dimana teknik ini digunakan untuk mengukur sikap, pendapat dan persepsi seseorang atau sekelompok orang tentang kejadian atau gejala sosial (Riduwan, 2003). Skala ini terdapat alternatif jawaban dengan nilai 5 sampai dengan 1 .

\section{Uji Instrumen}

Uji reliabilitas dilakukan dengan komputer program SPSS. Wiyono (2011), kriteria pengujian validitas adalah : jika $\mathrm{r}$ hitung $>\mathrm{r}$ tabel maka instrumen atau item-item pertanyaan berkorelasi signifikan terhadap skor total, maka dinyatakan valid, sedangkan jika $r$ hitung $<\mathrm{r}$ tabel maka instrumen atau item-item pertanyaan tidak berkorelasi signifikan terhadap skor total, maka dinyatakan tidak valid. Sedangkan kriteria pengujian reliabilitas adalah : jika $r$ hitung $>r$ tabel maka instrumen atau item-item pertanyaan berkorelasi signifikan terhadap skor total, maka dinyatakan reliabel, sedangkan jika $r$ hitung $<r$ tabel maka instrumen atau item-item pertanyaan tidak berkorelasi signifikan terhadap skor total, maka dinyatakan tidak reliabel. Instumen yang valid dan reliabel menjadi persyaratan mutlak untuk memperoleh hasil penelitian yang meyakinkan, sehingga uji instrumen mutlak harus dilaksanakan sebelum instrumen digunakan untuk mengambil data yang sesungguhnya.

\section{E. Analisis Data}

Di dalam menganalisis data, penulis menggunakan analisis kuantitatif dan menggunakan beberapa metode analisis, yaitu: (1.) Analisis Deskriptif dilakukan terhadap variabel iklim organisasi (X1), motivasi (X2), kedisiplinan (Y1), skills (Z) dan kinerja karyawan (Y2); (2.) Analisis Inferensial, metode analisis utama dalam penelitian ini akan dilakukan dengan menggunakan metode Structural Equation Modelling (SEM) berbasis Partial Least Square (PLS); dan (3.) Analisis jalur, yaitu melakukan analisis terhadap model jalur dari suatu diagram yang menghubungkan antara variabel eksogen, variabel eksogen/endogen, dan variabel endogen. 


\section{F. Kerangka Pikir}

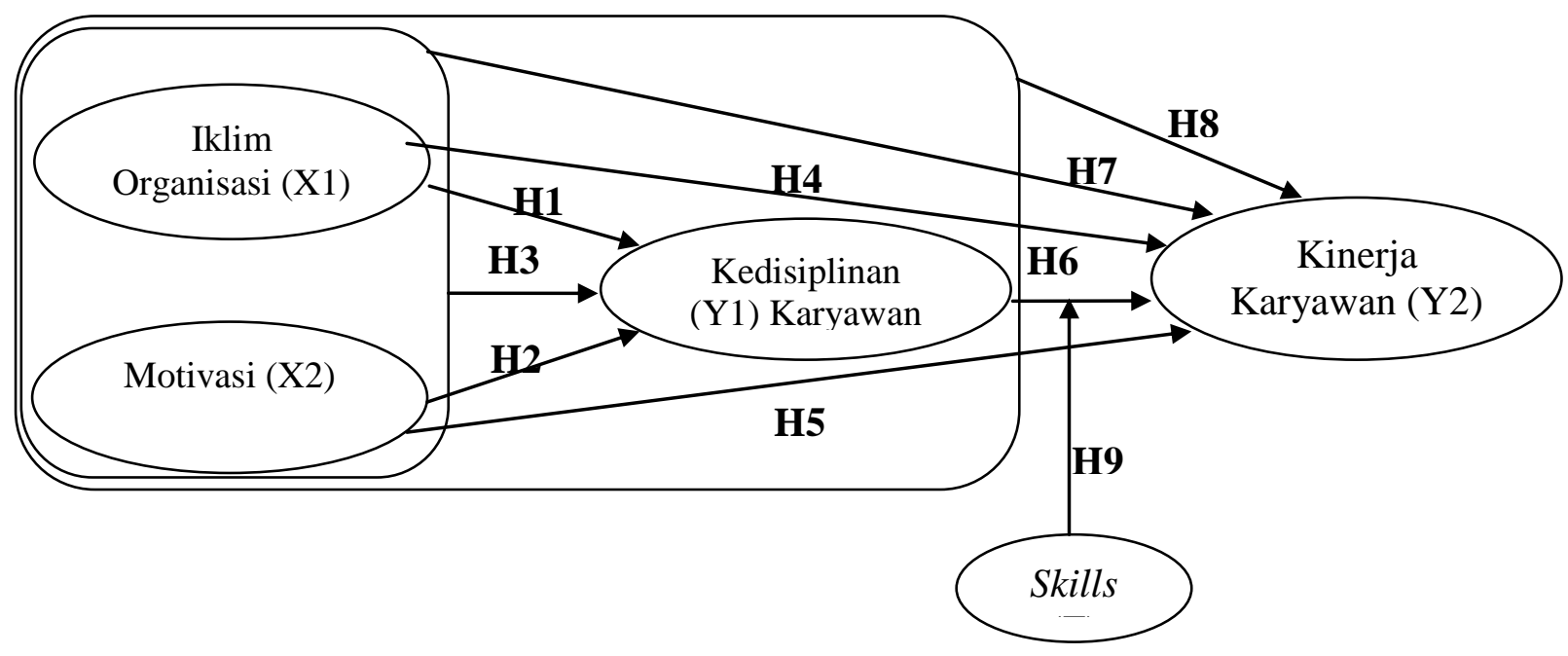

Gambar 2.1

Kerangka Pikir Penelitian

\section{G. Hipotesis}

Hipotesis dari penelitian ini adalah:

H1 Iklim organisasi berpengaruh terhadap kedisiplinan karyawan.

H2 Motivasi berpengaruh terhadap kedisiplinan karyawan.

H3 Iklim organisasi dan motivasi secara simultan berpengaruh terhadap kedisiplinan karyawan.

H4 Iklim organisasi berpengaruh terhadap kinerja karyawan.

H5 Motivasi berpengaruh terhadap kinerja karyawan.

H6 Kedisiplinan berpengaruh terhadap kinerja karyawan.

H7 Iklim organisasi dan motivasi secara simultan berpengaruh terhadap kinerja karyawan.

H8 Iklim organisasi, motivasi dan kedisiplinan secara simultan berpengaruh terhadap kinerja karyawan.

H9 Skills yang memperkuat kedisiplinan berpengaruh terhadap kinerja karyawan.

\section{HASIL DAN PEMBAHASAN}

\section{A. Hasil Uji Instrument (Data Primer)}

Hasil uji instrumen yang meliputi uji validitas dan uji reliabilitas dengan menggunakan bantuan komputer program SPSS adalah sebagai berikut :

1. Variabel Iklim Organisasi (X1) diukur dengan menggunakan 10 butir pernyataan.

2. Variabel Motivasi (X2) diukur dengan menggunakan 12 butir pernyataan.

3. Variabel Kedisiplinan (Y1) diukur dengan menggunakan 10 butir pernyataan 
4. Variabel Skills (Z) diukur dengan menggunakan 22 butir pernyataan.

5. Variabel Kinerja (Y2) diukur dengan menggunakan 22 butir pernyataan.

\section{B. Analisis Data}

\section{Analisis Deskriptif}

Dari 40 kuesioner penelitian yang terkumpul, selanjutnya dibuat tabulasi yang selanjutnya disajikan dalam tabel distribusi frekuensi sebagai berikut :

a) Variabel Iklim Organisasi (X1) mempunyai 10 butir pernyataan. Diketahui bahwa 42,5\% responden menyatakan sangat setuju terhadap iklim organisasi tahun 2012; 67,8\% responden menyatakan setuju; 3,75\% responden menyatakan ragu-ragu; dan $0,3 \%$ responden menyatakan kurang setuju; serta tidak terdapat butir soal yang mendapatkan jawaban ekstrim dari responden.

b) Variabel Motivasi (X2) mempunyai 12 butir pernyataan. Diketahui bahwa 22,5\% responden menyatakan bahwa motivasi pada LPPKS biasa saja; $42,5 \%$ responden menyatakan baik dan $35 \%$ responden menyatakan sangat baik.

c) Variabel Kedisiplinan (Y1) mempunyai 10 butir pernyataan. Diketahui bahwa $60 \%$ responden menyatakan bahwa kedisiplinan pada LPPKS baik dan $40 \%$ responden menyatakan sangat baik.

d) Variabel Skills (Z) mempunyai 22 butir pernyataan. Diketahui bahwa $5 \%$ responden menyatakan bahwa skills karyawan pada LPPKS biasa saja, 50\% responden menyatakan baik dan $45 \%$ responden menyatakan sangat baik.

e) Variabel Kinerja (Y2) mempunyai 22 butir pernyataan. Diketahui bahwa 5\% responden menyatakan bahwa kinerja karyawan pada LPPKS biasa saja, 60\% responden menyatakan baik dan $35 \%$ responden menyatakan sangat baik.

\section{Analisis Inferensial}

Analisis inferensial dalam penelitian ini menggunakan alat bantu komputer dengan sofware smartPLS yang pengujiannya dilakukan melalui pentahapan pengukuran Outer Model dan Inner Model. Gambar awal analisis inferensial dalam penelitian ini adalah sebagai berikut :

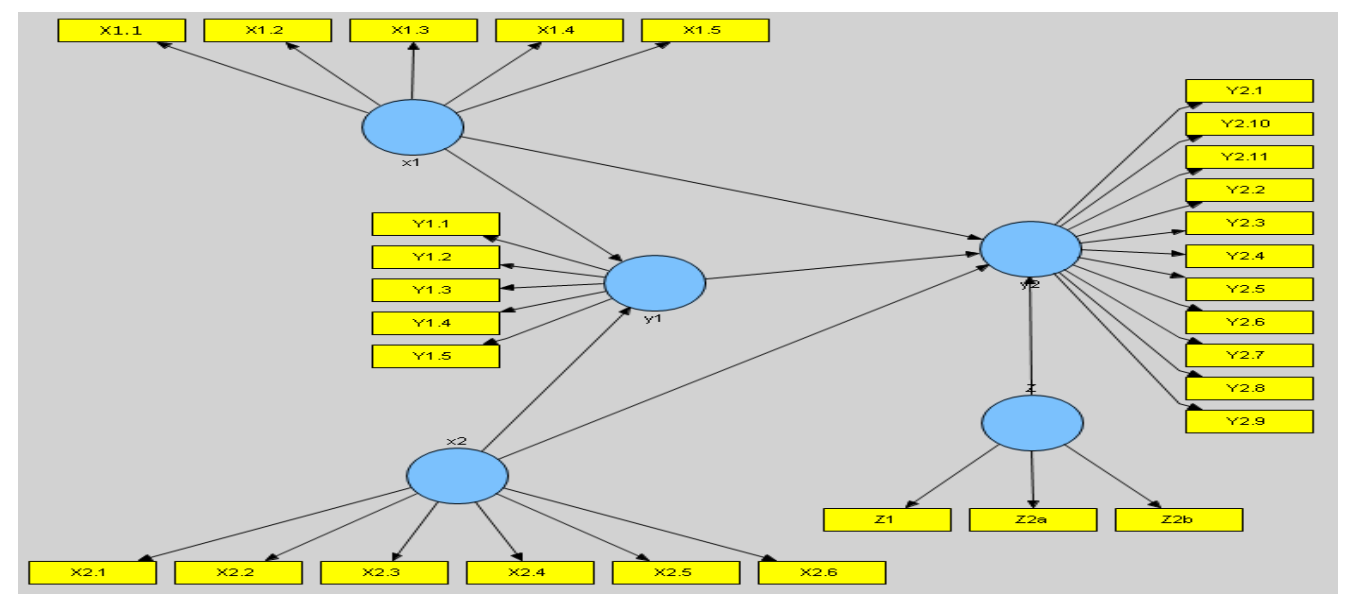

Gambar Model Sebelum Uji Indikator 


\section{a. Outer Model}

Outer model adalah model pengukuran yang menghubungkan indikator dengan variabel latennya yang diukur melalui convergent validity (Loading Factor), discriminan validity (Cross Loading) dan composite reliability. Adapun gambar outer model (hasil PLS Algorithm) adalah sebagai berikut :

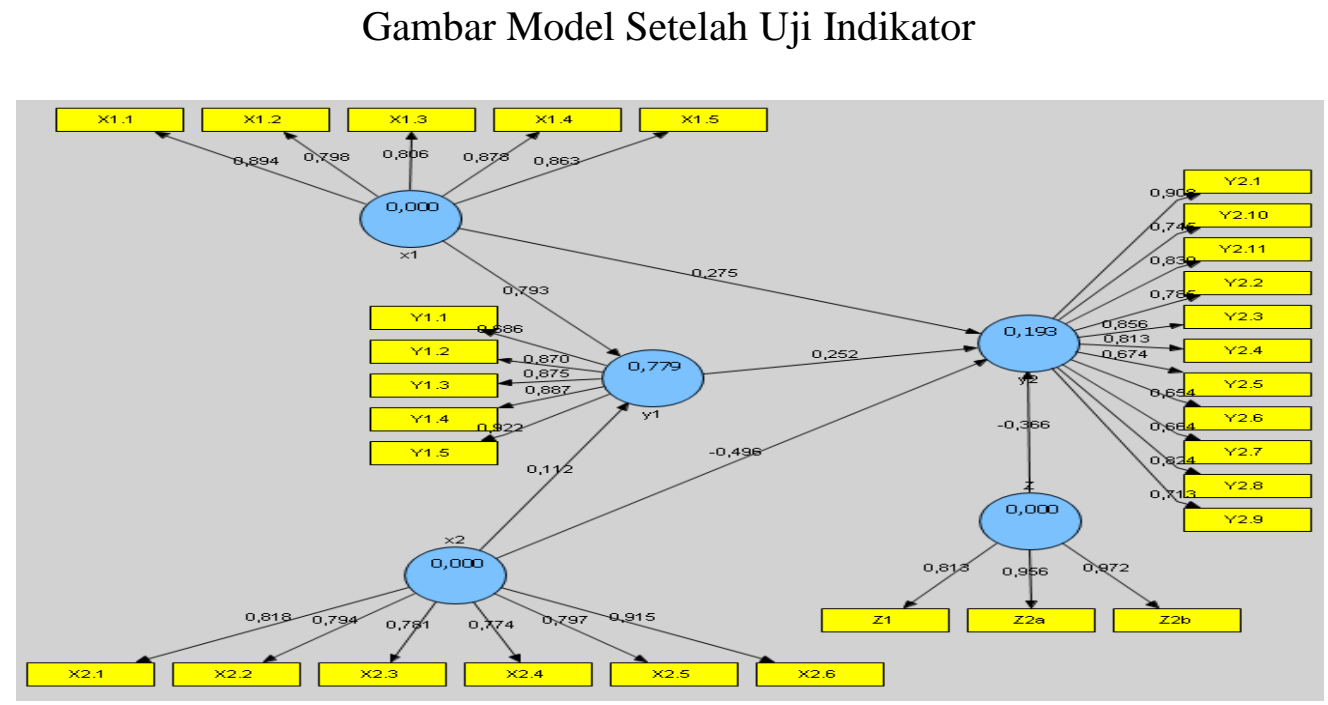

\section{b. Inner Model}

1) $R^{2}$ untuk variabel laten endogen

Tabel $R$ Square

\begin{tabular}{|c|c|}
\hline \multicolumn{2}{|c|}{ R Square } \\
\hline $\mathbf{Z}$ & \\
\hline $\mathbf{x} 1$ & \\
\hline $\mathbf{x} 2$ & 0,778742 \\
\hline $\mathbf{y 1}$ & \\
\hline $\mathbf{y 1} * \mathbf{Z}$ & 0,211886 \\
\hline $\mathbf{y 2}$ & \\
\hline
\end{tabular}

Sumber : Output smartPLS

Tabel di atas memberikan nilai 0,778742 untuk Y1 (kedisiplinan) yang berarti bahwa variabel X1 (iklim organisasi) dan X2 (motivasi) mampu menjelaskan variabel Y1 (kedisiplinan) sebesar $77,8742 \%$. Nilai $R$ juga terdapat pada $Y 2$ yaitu sebesar 0,211886 yang berarti bahwa variabel X1 (iklim organisasi), X2 (motivasi), Y1 (kedisiplinan) dan Z (skills) mampu menjelaskan variabel Y2 sebesar 21,1886\%.

2) Koefisien Parameter dan T-Statistik 
Tabel Koefisien Parameter dan T-Statistik

\begin{tabular}{|c|c|c|}
\hline & Original Sample (Koefisien Parameter) & T Statistics \\
\hline $\mathbf{Z}$-> y2 & 1,145424 & 1,184260 \\
\hline $\mathbf{x 1}$-> y1 & 0,792863 & 9,347776 \\
\hline $\mathbf{x} 1$-> $\mathbf{2}$ & 0,230842 & 0,850148 \\
\hline $\mathbf{x} 2$-> $\mathbf{1}$ & 0,111725 & 1,173515 \\
\hline $\mathbf{x} 2$-> $\mathbf{2}$ & $-0,437849$ & 3,284719 \\
\hline $\mathbf{y} 1$-> $\mathbf{2}$ & 1,689344 & 1,838086 \\
\hline $\mathbf{y} 1 * \mathbf{Z}$-> y2 & $-2,715014$ & 1,571946 \\
\hline
\end{tabular}

Sumber : Output smartPLS

\section{Analisis Jalur}

Tabel Koefisien Jalur dan T-Statistik

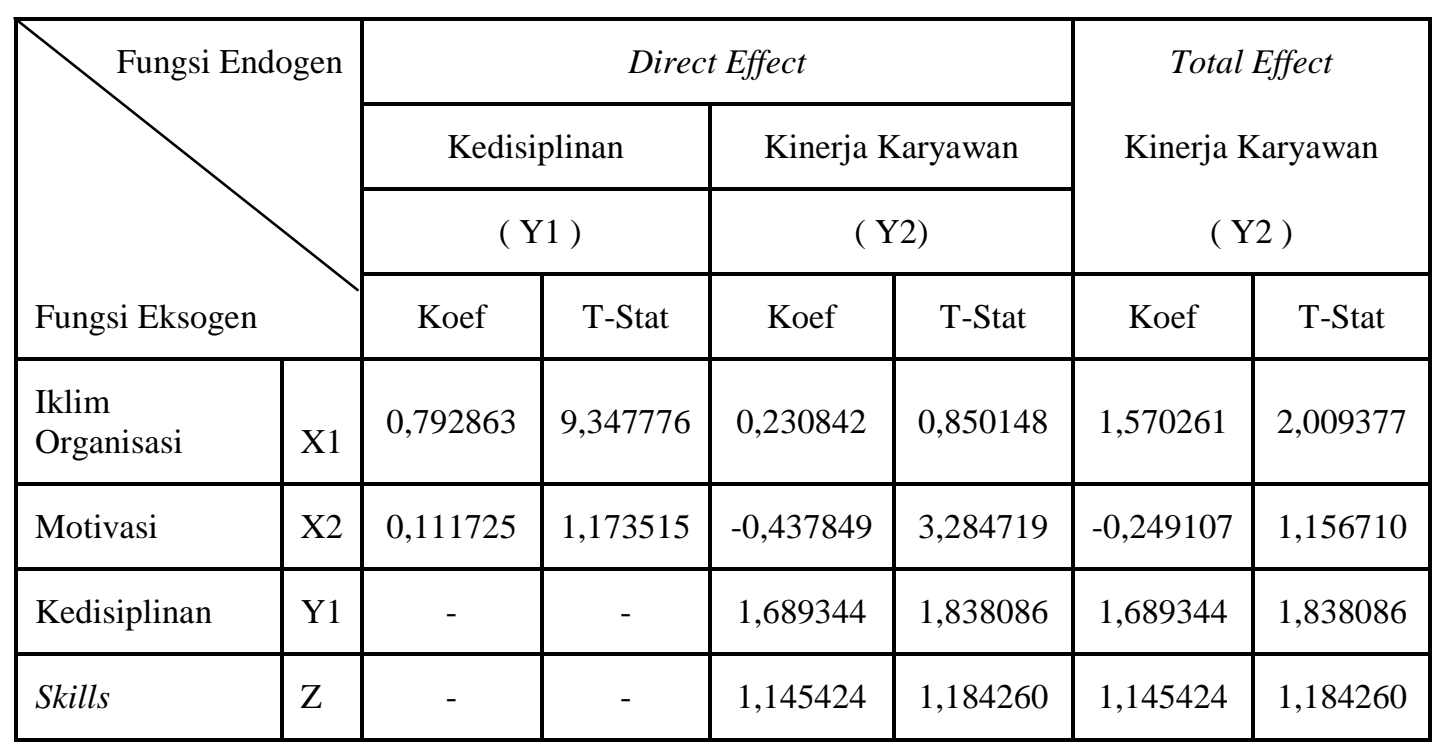

Sumber : Output smartPLS

\section{KESIMPULAN}

Berdasarkan analisis inferensial serta perhitungan pada tabel maka hasil pengujian hipotesis yang diajukan dalam penelitian ini adalah sebagai berikut:

A. Hipotesis 1 menyatakan bahwa iklim organisasi berpengaruh terhadap kedisiplinan karyawan terbukti. Dapat dilihat bahwa besarnya koefisien parameter dari pengaruh variabel iklim organisasi (X1) terhadap variabel kedisiplinan (Y1) sebesar 9,347776 yang artinya terdapat pengaruh positif dan signifikan dari variabel iklim organisasi terhadap variabel kedisiplinan. Nilai original sample sebesar 0,792863 yang artinya bahwa variabel iklim organisasi mampu menjelaskan variabel kedisiplinan sebesar 79,2863\%. Dengan kata lain bahwa semakin baik iklim organisasi maka kedisiplinan akan semakin tinggi. Hal ini sesuai dengan teori 
dikemukakan oleh Toulson dan Smith (1994) mendefinisikan iklim organisasi sebagai suatu yang dapat diukur pada lingkungan kerja baik secara langsung maupun tidak langsung berpengaruh pada karyawan dan pekerjaannya dimana tempat mereka bekerja dengan asumsi akan berpengaruh pada motivasi dan perilaku karyawan.

B. Hipotesis 2 menyatakan bahwa motivasi berpengaruh terhadap kedisiplinan karyawan terbukti. Dapat dilihat bahwa besarnya koefisien parameter dari pengaruh variabel motivasi (X2) terhadap variabel kedisiplinan (Y1) sebesar 1,173515 yang artinya terdapat pengaruh positif dan signifikan dari variabel kedisiplinan terhadap variabel motivasi. Nilai original sample sebesar 0,111725 yang artinya bahwa variabel motivasi mampu menjelaskan variabel kedisiplinan sebesar $11,1725 \%$. Hal ini berarti hipotesis 2 yang diajukan dapat diterima karena motivasi berpengaruh secara positif signifikan terhadap kedisiplinan. Dengan kata lain bahwa semakin baik motivasi maka kedisiplinan karyawan akan semakin tinggi. Hal ini sesuai dengan yang dikemukakan oleh Herzberg yang mengembangkan teori motivasi dua faktor, menurut teori ini ada dua faktor yang mempengaruhi kondisi pekerjaan seseorang, yaitu faktor pemuas (motivation factor) yang disebut juga dengan satisfier atau intrinsic motivation dan faktor kesehatan (hygienes) yang juga disebut disatisfier atau ekstrinsic motivation. Teori Herzberg ini melihat ada dua faktor yang mendorong karyawan termotivasi yaitu faktor intrinsik (daya dorong yang timbul dari dalam diri masing-masing orang) dan faktor ekstrinsik (daya dorong yang datang dari luar diri seseorang, terutama dari organisasi tempatnya bekerja). Jadi karyawan yang terdorong secara intrinsik akan menyenangi pekerjaan yang memungkinnya menggunakan kreaktivitas dan inovasinya, bekerja dengan tingkat otonomi yang tinggi dan tidak perlu diawasi dengan ketat. Sebaliknya, mereka yang lebih terdorong oleh faktor-faktor ekstrinsik cenderung melihat kepada apa yang diberikan oleh organisasi kepada mereka dan kinerjanya diarahkan kepada perolehan hal-hal yang diinginkannya dari organisasi (dalam Sondang, 2002).

C. Hipotesis 3 menyatakan bahwa iklim organisasi dan motivasi secara simultan berpengaruh terhadap kedisiplinan karyawan terbukti. Terlihat bahwa iklim organisasi terhadap kedisiplinan karyawan sebesar 79,2863\% dan motivasi terhadap kedisiplinan karyawan sebesar 11,1725\% sama-sama berpengaruh positif signifikan. Pada tabel 22 dapat dilihat bahwa R Square untuk kedisiplinan (Y1) sebesar 0,778742 dan memiliki nilai positif. Hal ini berarti hipotesis 3 yang diajukan dapat diterima karena iklim organisasi dan motivasi secara simultan berpengaruh secara terhadap kedisiplinan karyawan. Dengan kata lain bahwa semakin baik iklim organisasi dan motivasi maka kinerja karyawan akan semakin tinggi. Hal ini sesuai dengan teori yang dikemukakan oleh Toulson dan Smith (1994), yang menyatakan bahwa iklim organisasi adalah sesuatu yang dapat diukur pada lingkungan kerja baik secara langsung maupun tidak langsung berpengaruh pada karyawan dan pekerjaannya dimana tempat mereka bekerja dengan asumsi akan berpengaruh pada motivasi dan perilaku karyawan.

D. Hipotesis 4 menyatakan bahwa iklim organisasi berpengaruh terhadap kinerja karyawan terbukti. Dapat dilihat bahwa besarnya koefisien parameter dari pengaruh variabel iklim organisasi (X1) terhadap variabel kinerja pegawai (Y2) sebesar 0,850148, yang artinya terdapat pengaruh positif dan signifikan dari variabel iklim organisasi terhadap variabel kinerja karyawan. Nilai original sample sebesar 0,230842 yang artinya bahwa variabel iklim organisasi mampu menjelaskan variabel kinerja karyawan sebesar $23,0842 \%$. Hal ini berarti hipotesis 4 yang diajukan dapat diterima karena iklim organisasi berpengaruh secara positif signifikan terhadap kinerja karyawan. Dengan kata lain bahwa semakin baik iklim organisasi maka kinerja karyawan akan semakin tinggi. Hal ini sesuai dengan teori yang dikemukakan oleh Toulson dan Smith (1994), yang menyatakan bahwa iklim organisasi adalah sesuatu yang dapat diukur pada lingkungan kerja baik secara langsung maupun tidak langsung berpengaruh pada karyawan dan pekerjaannya dimana tempat mereka bekerja dengan asumsi akan berpengaruh pada motivasi dan perilaku karyawan. 
E. Hipotesis 5 menyatakan bahwa motivasi berpengaruh terhadap kinerja karyawan terbukti. Dapat dilihat bahwa besarnya koefisien parameter dari pengaruh variabel motivasi (X2) terhadap variabel kinerja karyawan (Y2) sebesar 3,284719 dan nilai original sample sebesar -0,437849 yang artinya bahwa motivasi mempunyai pengaruh yang kecil dalam meningkatkan kinerja. Pengaruh ini membuat fenomena baru yang berbeda dari hasil penelitian yang dilakukan Etykawaty (2005), yang menunjukkan bahwa motivasi dan kedisiplinan secara parsial dan serentak berpengaruh secara signifikan terhadap kinerja petugas pemasyarakatan.

F. Hipotesis 6 menyatakan bahwa kedisiplinan berpengaruh terhadap kinerja karyawan terbukti. Dapat dilihat bahwa besarnya koefisien parameter dari pengaruh variabel kedisiplinan (Y1) terhadap varibel kinerja karyawan (Y2) sebesar 1,838086, yang artinya terdapat pengaruh positif dan signifikan dari variabel motivasi terhadap variabel kinerja karyawan. Nilai original sample sebesar 1,689344 yang artinya bahwa variabel kedisiplinan mampu menjelaskan variabel kinerja karyawan sebesar 16,89344\%. Hal ini berarti hipotesis 6 yang diajukan dapat diterima karena kedisiplinan berpengaruh secara positif signifikan terhadap kinerja karyawan. Dengan kata lain bahwa semakin baik kedisiplinan maka kinerja karyawan akan semakin tinggi. Hal ini sesuai dengan teori dan atau hasil penelitian yang dilakukan oleh Etykawaty (2005), yang menunjukkan bahwa motivasi dan kedisiplinan secara parsial dan serentak berpengaruh secara signifikan terhadap kinerja petugas pemasyarakatan.

G. Hipotesis 7 menyatakan bahwa iklim organisasi dan motivasi secara simultan berpengaruh terhadap kinerja karyawan terbukti. Terlihat bahwa iklim organisasi sebesar 23,0842\% terhadap kinerja karyawan dan motivasi mempunyai pengaruh yang kecil terhadap kinerja karyawan. Hal ini menyatakan bahwa motivasi tidak terlalu berpengaruh secara simultan dengan iklim organisasi terhadap kinerja karyawan. Hal ini hampir sama dengan hasil penelitian yang dilakukan oleh Sri Rahayu Dwi Purnaningtyas (2011), menunjukkan bahwa berdasarkan hasil analisis data dan pembahasan diperoleh : (1) Tidak ada pengaruh yang signifikan antara motivasi belajar terhadap prestasi belajar; (2) Tidak ada pengaruh yang signifikan antara soft skills terhadap prestasi; (3) Tidak ada pengaruh yang signifikan antara motivasi belajar dan soft skills terhadap prestasi belajar.

H. Hipotesis 8 menyatakan bahwa iklim organisasi, motivasi, dan kedisiplinan secara simultan berpengaruh terhadap kinerja karyawan terbukti. Terlihat bahwa nilai R Square pada tabel 22 untuk nilai kinerja karyawan (Y2) sebesar 0,211886 yang memiliki nilai positif. Hal ini menyatakan bahwa iklim organisasi, motivasi, dan kedisiplinan secara simultan berpengaruh terhadap kinerja karyawan. Motivasi tidak terlalu berpengaruh secara simultan dengan iklim organisasi terhadap kinerja karyawan. Hal ini ini sesuai dengan hasil penelitian yang dilakukan oleh Etykawaty (2005) yang menunjukkan bahwa motivasi dan kedisiplinan secara parsial dan serentak berpengaruh secara signifikan terhadap kinerja.

I. Hipotesis 9 menyatakan bahwa skills yang memperkuat kedisiplinan berpengaruh terhadap kinerja karyawan terbukti. Dapat dilihat bahwa besarnya koefisien parameter dari pengaruh variabel skills (Z) terhadap variabel kinerja (Y2) sebesar 1,184260 yang artinya terdapat pengaruh positif dan signifikan dari variabel skills terhadap variabel kinerja. Nilai original sample sebesar 1,145424 yang artinya bahwa variabel motivasi mampu menjelaskan variabel kinerja sebesar $11,45424 \%$. Hal ini berarti hipotesis 9 yang diajukan dapat diterima karena skills berpengaruh secara positif signifikan terhadap kinerja karyawan. Dengan kata lain bahwa semakin baik skills maka kinerja karyawan akan semakin tinggi. Hal ini sesuai dengan hasil penelitian yang dilakukan oleh Faizal Alam Islami (2012) yang menunjukkan bahwa urutan secara individu dari masing-masing variabel yang paling berpengaruh adalah variabel Soft Skill, variabel motivasi, dan variabel hard skills. 
Berdasarkan analisis deskriptif, analisis inferensial, analisis jalur serta pembahasan diatas, selanjutnya dapat ditarik kesimpulan sebagai berikut :

1. Terdapat karyawan yang masih belum puas dengan cara penyelesaian permasalahan pada organisasi di LPPKS yang menjadikan kedisiplinannya pun menurun.

2. Tidak semua karyawan diikutserakan dalam semua pekerjaan yang menyangkut tupoksi lembaga.

3. Tidak semua karyawan diberikan petunjuk dari atasan sebelun mengerjakan pekerjaannya.

4. Tidak semua karyawan dapat memanajemen stress nya dengan baik dan tidak semua karyawan memiliki sifat kepemimpinan pada diri sendiri.

5. Dalam kapasitas penilaian kinerja yang dilakukan oleh atasan terdapat karyawan yang tidak memiliki sifat kepemimpinan dalam mengerjakan pekerjaannya pada lembaga dan tidak semua karyawan dapat memotivasi rekan kerjanya dalam melaksanakan pekerjaan yang menjadi visi dan misi lembaga.

6. Iklim organisasi, motivasi dan kedisiplinan secara parsial maupun secara bersama-sama berpengaruh signifikan positif terhadap kinerja karyawan pada LPPKS tahun 2012. Secara parsial iklim organisasi berpengaruh terhadap kedisiplinan sebesar 79,2863\%; motivasi berpengaruh terhadap kedisiplinan sebesar 11,1725\%; R Aquare kedisiplinan 0,778742; iklim organisasi berpengaruh terhadap kinerja karyawan sebesar 23,0842\%; motivasi tidak terlalu berpengaruh terhadap kinerja karena nilai original sample nya sebesar -0,437849; kedisiplinan berpengaruh terhadap kinerja sebesar 16,89344\%; iklim organisasi dan motivasi secara simultan berpengaruh terhadap kinerja karyawan; iklim organisasi, motivasi, dan kedisiplinan secara simultan brpengaruh terhadap kinerja karyawan terlihat dari R Square Kedisiplinan sebesar 0,211886; dan skills berpengaruh terhadap kinerja sebesar 11,45424\%. Hal ini menunjukkan bahwa semakin baik iklim organisasi, motivasi, kedisiplinan, dan skills maka kinerja karyawan akan semakin meningkat.

7. Iklim organisasi lebih berpengaruh terhadap kedisiplinan dibandingkan terhadap kinerja karyawan. Terhadap kedisiplinan sebesar 0,792863 (T-stat 9,347776) sedangkan terhadap kinerja karyawan sebesar 0,230842 (T-stat 0,850148), namun demikian pengaruhnya sama-sama positif. Hal ini menyebabkan total effect-nya naik menjadi 1,570261 (T-stat 2,009377). Motivasi lebih berpengaruh terhadap kedisiplinan dibandingkan terhadap kinerja. Terhadap kedisiplinan sebesar 0,111725 (T-stat 1,173515) sedangkan terhadap kinerja karyawan sebesar -0,437849 (T-stat 3,284719). Hal ini menyebabkan total effect-nya menjadi -0,249107 (T-stat 1,156710). Kedisiplinan berpengaruh terhadap kinerja sebesar 1,689344 (T-stat 1,838086). Skills karyawan berpengaruh positif terhadap kinerja karyawan sebesar 1,145424 (T-stat 1,184260). Memperhatikan kondisi tersebut dapat dikatakan bahwa iklim organisasi lebih berpengaruh terhadap kedisiplinan dibandingkan dengan kinerja karyawan, motivasi lebih berpengaruh terhadap kedisiplinan dibandingkan dengan kinerja, kedisiplinan berpengaruh terhadap kinerja karyawan dan skills berpengaruh terhadap kinerja karyawan. Dengan melihat fenomena tersebut dapat dikatakan bahwa LPPKS dalam rangka meningkatkan kinerja karyawan perlu memperhatikan faktor kedisiplinan dan skills karyawan.

Selanjutnya diajukan saran untuk perbaikan kinerja karyawan pada LPPKS Indonesia sebagai berikut :

1. Pimpinan pada semua level hendaknya dapat menyelesaikan semua perbedaan pendapat yang terjadi diantara karyawan dengan cara musyawarah dan mufakat. 
2. Pimpinan pada semua level hendaknya memberikan kesempatan kepada semua karyawan yang berkompeten agar dapat mengikuti semua kegiatan yang menyangkut tupoksi lembaga.

3. Pimpinan pada semua level hendaknya memberikan petunjuk kepada bawahan tentang apa yang seharusnya mereka lakukan sebelum mengerjakan suatu pekerjaan.

4. Pimpinan hendaknya membantu karyawan agar dapat memanajemen stress nya dengan baik, dan menumbuhkan sifat kepemimpinan yang akan membuat mereka dapat mengerjakan pekerjaannya dengan baik tanpa harus selalu bertanya apa yang harus dilakukan.

5. Agar penilaian kinerja yang dilakukan atasan memiliki nilai yang baik, maka sifat kepemimpinan dalam diri tiap-tiap karyawan harus selalu ditanamkan dan setiap karyawan dapat memotivasi rekan kerjanya dalam melaksanakan pekerjaan yang menjadi visi dan misi lembaga.

6. Variabel yang paling dominan mempengaruhi kinerja adalah kedisiplinan. Sehingga dalam rangka meningkatkan kinerja semua karyawan harus memiliki rasa kedisiplinan yang tinggi.

7. Skills sebagai variabel moderating memiliki peran yang sangat penting dalam meningkatkan kinerja karyawan, terlihat dari hasil yang signifikan apabila dibandingkan dengan tidak adanya skills dalam penelitian ini. Sehingga dalam rangka meningkatkan kinerja karyawan, skills harus selalu dikembangkan dan ditingkatkan.

\section{DAFTAR PUSTAKA}

A.A. Anwar, P. M., 2007, Manajemen Sumber Daya Manusia Perusahaan, PT. Remaja Rosdakarya. Bandung.

Byars \& Rue, 1995, Manajemen Pelayanan, Yogyakarta: Pustaka Pelajar.

Davis, K \& John W. N., 1997. Organizational Behavior - Human Behavior at work. Tenth Edition McGraw- Hill. International Edition. New York.

Dessler, G., 2000, Manajemen Sumber Daya Manusia, Edisi terjemahan. Penerbit PT. Prenhallindo. Jakarta.

Forehand \& Gilmer, 1964, Environmental variations in organisational climate. Psychological bulletin.

Hafis Mu'addab (hafismuaddab.wordpress.com).

Hasibuan, M.S.P., 1996, Manajemen Sumber Daya Manusia. Bumi Aksara, Jakarta.

Hasibuan, M.S.P., 2001, Manajemen Sumber Daya Manusia. Jakarta : PT. Bumi Aksara.

Hasibuan, M., 2005, Manajemen Sumber Daya Manusia. Bumi Aksara, Jakarta.

Mohammad, M., 2006, Pengukuran Kinerja Sektor Pelayanan Publik. Yogyakarta: BPTE.

Mangkunegara, A., 2001, Manajemen Sumber Daya Manusia. Bandung: PT. Remaja Rosdakarya.

Nawawi, H., 2000, Manajemen Sumber Daya Manusia Untuk Bisnis yang Kompetitif. Gajah Mada University Press. Yogyakarta.

Peraturan Pemerintah Nomor 53 tahun 2010 tentang Peraturan Disiplin Pegawai Negeri Sipil

Pratiwi, I.S.P.A, 2005, Sukses dengan Soft Skills. Bagaimana Meningkatkan Kemampuan Interaksi Sosial Sejak Kuliah. Direktorat Pendidikan Institut Teknologi Bandung.

Prawirosentono, S., 1999, Manajemen Sumber Daya Manusia. Kebijakan Kinerja Karyawan. BPFE. Yogyakarta. 
Purnomosidhi, 1996, Praktik Pengungkapan Modal Intelektual pada Perusahaan Publik di BEJ. Jurnal Riset Akuntansi Indonesia.

Rivai, V., 2008, Manajemen Sumber Daya Manusia untuk Perusahaan. PT.Raja Grafindo Persada: Jakarta.

Robbins, D.S.P., 2000, Human Resource Management Conceptand Practice. Jakarta. PT. Preenhalindo.

Robert, S., 2002, Leadership and Organization Climate. Premtice Hall. New Jersey.

Sailah, I., 2008, Pengembangan Soft Skills Di Perguruan Tinggi. Jakarta : Direktorat Jenderal Pendidikan Tinggi.

Simamora, H., 2001, Akuntansi Manajemen. Jakarta. Salemba Empat.

Suyadi, P., 1997, Kebijakan Kinerja Karyawan. Yogyakarta: BPFE.

Sarwoto, 1979, Dasar-dasar Organisasi Manajemen. Jakarta:Ghalia Indonesia.

Sedarmayanti, 2007, Sumber Daya Manusia dan Produktivitas Kerja. Bandung. Penerbit Mandar Maju. Wibowo (2007).

Soekanto, S., 2001, Sosiologi. Jakarta: PT Rajagrafindo Persada.

Siagian, S.P., 2003, Teori dan Praktek Kepemimpinan. PT. RINEKA CIPTA Jakarta.

Siagian, S.P., 1995, Manajemen Sumber Daya Manusia. Jakarta. PT. Elek Media Kompetindo.

Suprihanto, 2000, Manajemen Sumber Daya Manusia. Universitas Terbuka, Karunika, Jakarta.

Tarmidi, dan Rambe, Rahma, A.R., 2010, Korelasi Antara Dukungan Sosial Orang Tua dan Self-Directed Learning pada Siswa SMA. Universitas Sumatra Utara.

Tjahjono, H.K. 2015. Metode Penelitian Bisnis. VSM MM UMY

Toulson, P. \& Mike, Smith, 1994, The Relationship Between Organizational Climate and Employee Perceptions of Personnel Management Practices. Journal of Public Personnel Management. 